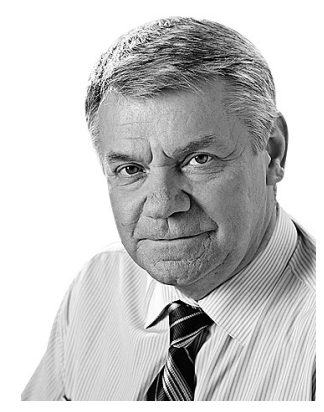

\section{Evgeny V. POPOV}

Corresponding Member of the Russian Academy of Sciences, Dr. Sc. (Econ.), Head of the Center for Economic Theory

Institute of Economics (Ural branch of RAS)

29 Moskovskaya St., Yekaterinburg, Russia, 620014

Head of Political Economy Dept.

Ural State University of Economics

62/45 8 Marta/Narodnoy Voli St., Yekaterinburg, Russia, 620144

Phone: (343) 371-45-36

e-mail:epopov@mail.ru

\title{
Econotronics of the Digital Society ${ }^{1}$
}

The paper systematises elements of analysis of modern digital society within the author's concept of econotronics. It shows that econotronics is a subdiscipline of social sciences devoted to the dynamics of economic institutions of interaction between actors and society in digital economy. The author analyses research subject of econotronics and on the basis of the modern notion of homo institutionalis argues that the most adequate toolkit to model the processes of digital society development are tools of institutional economics. The research reveals elements of institutional design of econotronics' transactions, identifies directions for institutional modelling of the subject of econotronics, and emphasises that econotronics is a scientific concept for modelling of the digital society development.

JEL classification: A10, B16, B52

Keywords: digital society; econotronics; homo institutionalis; institutional design; modelling.

\section{Introduction}

$\mathrm{M}$ odern economic development largely relies on introduction and implementation of advanced information technologies. Traditional economic methods are substantially complemented, and in some cases replaced, by modern methods of accounting and redistribution of assets. To the greatest extent, this can be seen in the economy of public sector, where low-cost entrepreneurship is a driving force of economic development. In this case, a forming digital society seeks the most adequate, leading-edge methods for modelling of economic activities. However, the world economic literature has not properly addressed the problem of analysing modern digital society from the perspective of rational economy management as yet.

The research aims to develop elements of analysis of modern digital society within the author's concept of econotronics.

The logic of the research appears as follows: first, to examine the research subject of econotronics; second, to determine possibilities for applying institutional economics to describe it; third, to discuss principles of institutional design of econotronics' transactions and methods of their institutional modelling. As a result of the research, econotronics will receive evaluation as a scientific concept used for modelling of the digital society development.

\section{Research subject of econotronics}

Several concepts can be applied to describe driving forces behind the development of modern society: sociodynamics, socioeconomics, constitutional economics and some others.

Sociodynamics is a subfield of sociology devoted to quantitative methods of modelling of interactions between both individuals and public structures ${ }^{2}$. However, institutional

${ }^{1}$ The reported study was funded by RFBR according to the research project no. 17-06-00281 "Modelling of the institutional environment of Russia's socioeconomic development".

${ }^{2}$ Sociodynamics. Available at: http://socio.escience.ifmo.ru/wiki/index. 
interactions do not always have quantitative measurement, more often they are assessed only qualitatively, therefore, application of the sociodynamics concept for institutional modelling of modern production is not entirely appropriate.

Socioeconomics is a research programme founded by Amitai Etzioni, who suggested considering an individual as having at least two basic needs and two sources of judgement: satisfaction and morality [14]. Yet presence of morals is just one limitation to human behaviour. From this standpoint, an institutional view offers a more comprehensive and systemic approach to the analysis of formal and informal norms and rules restricting individuals' behaviour.

Constitutional economics is a research programme that describes mutual influence of legal and economic factors in the state decision-making, as well as interactions of Constitution application problems with the structure and functioning of an economy ${ }^{1}$. Nonetheless, driving forces behind the development of modern economic systems are often generated by innovators who do not allow for problems of constitutional rights' application.

Hence, to describe the development of modern driving forces it is relevant to involve a concept that takes into consideration new social trends. Such concept was formulated by Alvin Gouldner. In his opinion, sociotronics is the name of the concept according to which exclusively informatization of modern society is capable of counteracting existing social pathologies and deviations. Then, experts directly engaged in information, communication and computerization processes are the major actors of social rehabilitation [13]. Obviously, economic sociotronics is the closest to the research subject, driving forces of modern economics. In a shorter variant, econotronics.

Consequently, econotronics is a subfield of social sciences studying the development dynamics of economic institutions of interaction between actors and society in a modern digital economy [7]. It is worth pointing out that this concept is consonant with a number of natural science disciplines: electronics (the science of electrons' interaction with electromagnetic fields and methods of creating electronic devices); chemotronics (a discipline dealing with the fundamental and applied aspects of electrochemical processes occurring at the electrode-electrolyte interface); biotronics (an interdisciplinary programme on creation of artificial biogeocenoses (i.e. systems including a community of living organisms and a set of environmental factors connected with it).

What is then the research subject of econotronics?

In the broadest sense, the subject of econotronics includes modern methods of economic management conditioned by implementation of advanced digital technologies. The subject of econotronics encompasses social innovations, crowdfunding and other economic processes, which gained traction within a modern digital society. A typical subject of econotronics is sharing economy and blockchain technology.

Sharing economy is a technology of rational economic management, which implies that consumers of products and services are actively involved (participate) in development of these products and services. This method of economic management has been known since the ancient times, however it has become widely applied with the spread of digital technologies, first and foremost, with the development of the Internet.

Blockchain is a multifunctional and multilevel information technology designed for reliable accounting of various assets [21].

In a narrower sense, a modelled representation, the research subject of econotronics includes economic institutions of interaction between actors and society. At this, the analysis of development dynamics of these institutions is important.

Let us emphasize that the analysis of economic institutions seems to be particularly relevant for the analysis of digital society, because established rules and norms underlie interaction of individuals in such a society.

${ }^{1}$ Constitutional economics. Available at: https://ru.wikipedia.org/wiki. 


\section{Homo institutionalis vs homo economicus}

Karl Marx and Friedrich Engels wrote that "the way in which men produce their means of subsistence depends first of all on the nature of the actual means of subsistence they find in existence and have to reproduce. This mode of production must not be considered simply as being the production of the physical existence of the individuals. Rather it is a definite form of activity of these individuals, a definite form of expressing their life, a definite mode of life on their part" [4].

"A definite mode of life on their part" was used in the studies of Thornstein Veblen, the founder of classical institutionalism, as a concept of institution, which he regarded as "...habits of thought inherent in all members of the community" [24].

On the other hand, T. Veblen was peculiar to the state. He extolled management as the most important regulatory system, but did not see the necessity in the state, considering it an "abnormal" institution [23]. According to T. Veblen, "abnormality" of the state as an institution consisted in the development of patriotic feelings by strengthening various ceremonies and predatory instincts. At the same time, it is generally accepted that it was T. Veblen who drew attention to the category "institution" as the basis for the economic analysis of economic activity.

Consequently, in this study, institutions will be understood as the established norms of interaction between economic agents (in the presence of control over these interactions) [6. P. 28].

In economic literature, we can find a broader interpretation of institutions - not only as norms of interaction between economic agents, but also as organisational forms of combining economic agents [17]. Such a broad interpretation of the concept "institution" leads to the possibility of a numerical evaluation of the formation of certain organisations [3]. In this study, we will adhere to a more common interpretation of the concept "institution", which allows defining the method for studying economic systems more clearer [5].

We should emphasize that the institutional description of economic systems cannot have a zero level like a neoclassical equilibrium. In the study of Geoffrey Hodgson [10] it was shown that an important methodological problem of describing the evolution of institutions concerns any attempt to explain the emergence of institutions in the situation of a natural preinstitutional state. Any such attempt reaches an impasse because of an inevitable need to recognize initial availability of other institutions such as, for example, language. Hence, a notable feature of recent works on new institutionalism is recognition of the presence of some basic institutions as a starting point for analysis.

Once we admit, further notes Hodgson, that human activity can be studied only in the context of some already existing institutions, we can focus on the effects of institutional constraints and the "reverse explanations" in relation to individuals, as well as understand how the interaction between individuals leads to the emergence of new forms of institutions. We suggest the following: the impact of institutional opportunities and constraints on appropriate habits, ways of thinking and behaviour can contribute to the emergence and development of certain institutions. These statements point to a more open approach to the evolution of institutions, a decrease in the role of static comparison in favour of a more process-focused, algorithm analysis. In terms of the evolution of institutions and individual preferences, such arguments remind of "old" institutionalism, despite the fact that the detailed definition of the mechanisms of the "reverse explanations" has not yet been reflected in the research.

Institutions are structural entities that restrict individuals and influence their behaviour. Accordingly, if institutions influence individuals, they need to be considered separately. In turn, their existence is determined by the actions of other individuals. When will this infinite chain of analysis be interrupted? The goals of individuals can be partially explained with the help of relevant institutions, the cultural environment and so on. The same institutions must 
be subordinated to the interests of other individuals. And so on, down to infinity. We face an infinite reverse row of explanations, similar in meaning to a well-known riddle: "which came first, the chicken or the egg?". Such an analysis has no final result. We can stop at one of the stages and say: "everything depends on individual preferences" or stop at another and assume that everything is determined by institutional factors. But in the infinite reverse row of explanations, none of these hypotheses has superiority over the other.

Institutional function of institutions implies that a kind of order or relative stability can be achieved with all the diversity and differences at the microeconomic level. The existence of institutions presupposes that rules, restrictions, customs and ideas can, with the help of certain psychological and social mechanisms, change the individual goals and preferences in a certain way. This change can increase the possibility of institutions' emergence and contribute to their stability.

As A.M. Sergeev highlights [8] that compared to neoclassical theory the methodological specifics of new institutionalism consist in that new institutionalists pursue the principle of methodological individualism more consistently. According to this principle, all communities are subject to explanation from the perspective of the purposeful behaviour of their members (agents). In addition to the resource and technological constraints that are characteristic of neoclassical models of rational choice, a new class of constraints conditioned by institutional factors is introduced. The behavioural prerequisites for analysis are fundamentally modified by introducing the principles of bounded rationality and economic opportunism [2. P. 654-656].

In this sense, within the framework of modern institutionalism, three-level schemes for the study of economic systems are in demand [11. P. 42]. At the first level of this scheme there is an individual represented in institutional theory as homo institutionalis (contractual man) instead of homo economicus (economic man) in the neoclassical theory. The second level corresponds to various institutional agreements, the third - to the institutional environment.

The institutional description of an economic system is based on the methodological approach of Douglass North, which consists of the following main propositions [1].

1. Only individuals can have their own interests and pursue their goals.

2. Formal and informal sets of institutions always form the framework of individuals' interaction and affect it.

3. Formal and informal institutional changes always result from individuals' interaction in specific situations.

In other words, on the one hand, an individual is restricted by existing institutional structure, and on the other hand, can change this structure in accordance with his/her preferences.

Therefore, the core of institutional description of economic systems is the evolutionary nature of institutional structures' development. In this sense, modern institutional theory is closely linked with evolutionary economic theory and can be viewed as a single whole, as the institutional and evolutionary theory.

A modern digital society changes types of social networks and, as a result, establishes new relationships in the form of institutional infrastructure [16]. Digital society puts forward the problem of agreements between agents, their consent to interact under existing conditions [15].

Consequently, digital society, in which the adopted rules and constraints are the main elements, can best be described within the framework of institutional economic theory.

\section{Institutional design of digital economy}

The most representative areas of digital economy are sharing economy and the use of blockchain technology. The table presents examples of activities within sharing economy.

Apparently, the following set of principles of institutional design characterize the properties (connectivity, resourcing, specificity) of sharing economy. 
First, the efficiency of sharing economy is determined by the presence of highly branched communications, including mobile communications and the Internet. Without digital technologies, sharing economy loses its meaning, as the efficiency of communications with consumers is lost.

Examples of activities within sharing economy

\begin{tabular}{|c|c|c|}
\hline Type & Activity & Examples \\
\hline \multirow[t]{5}{*}{ Services } & Driving opportunities & Blablacar \\
\hline & Timesharing & Room4exchange \\
\hline & Allowing to use tools and space in a repair shop & Selfservegarage.com \\
\hline & Meal sharing & BonAppetour \\
\hline & Taxi sharing & Uber, YandexTaxi \\
\hline \multirow[t]{7}{*}{ Things } & Exchanging & \multirow[t]{7}{*}{ OLX, Allegro, EBay, Amazon } \\
\hline & Borrowing & \\
\hline & Donating & \\
\hline & Bartering & \\
\hline & Leasing & \\
\hline & Renting & \\
\hline & Reselling & \\
\hline \multirow[t]{2}{*}{ Resources } & Reusing of energy and other common resources & Vanderbron in Netherlands \\
\hline & Reusing of food & Food Combay, Food Loop \\
\hline \multirow[t]{2}{*}{ Know-how } & Co-using and developing & Open sources platforms \\
\hline & Teaching /learning & $\begin{array}{l}\text { Open source courses, online lectures, } \\
\text { virtual study groups }\end{array}$ \\
\hline \multirow[t]{4}{*}{ Finance } & Lending & Lending platforms \\
\hline & Currencies & Bitcoin \\
\hline & Insurance & Insurance policy pooling \\
\hline & $\begin{array}{l}\text { Collaborative money optimization and invest- } \\
\text { ments }\end{array}$ & Cash pooling \\
\hline
\end{tabular}

Note. Based on [22].

Second, the implementation of sharing economy procedures is possible if there are the resources necessary to perform the transfer to consumers. Under this approach resourcing is the basis for the movement of goods and services.

Third, the utility of implementing sharing economy procedures results from the specificity of assets transferred to the use of consumers. This is the case when consumers are ready to participate in the shared use of good instead of purchasing products or services.

Proceeding from the properties of blockchain technology (specification of rules, distribution of resources, availability of information) we can formulate the following principles of institutional design of econotronics' transactions.

Efficiency of employing blockchain is determined by the specification of rules of using information resources, which provides users' access codes to blockchain.

Economic relevance of employing blockchain is conditioned by spatial distribution of the accounted assets. The feature of dispersed resources is typical of both real goods, and virtual reality (voting, reputation support, insurance, etc.).

The consumer value of adopting blockchain proceeds from the availability of information for users of this technology. Availability of information provides both a multilateral surveillance over blockchain services, and a possibility to instantly utilize the results of accounting of different assets.

What are then possible methods of institutional modelling of the econotronics' subject? 


\section{Institutional modelling of digital society}

Institutional modelling of digital society within the concept of econotronics can be done by the methods of matrix, parametric, graphical and analytical modelling. Let us consider the last one in more detail.

Analytical modelling is based on establishing causal relationships between various parameters of the object of analysis expressed in formula dependencies.

An example of the analytical institutional modelling is the author's formalization of firm's transaction function.

The analysis of the published research on introducing the transaction function shows that such function can be designed on the basis of classical definitions of the essence of transaction costs followed by verification of the developed ratio.

A classical definition of transaction costs belongs to Thrainn Eggertsson: "in general terms, transactions costs are the costs that arise when individuals exchange ownership rights to economic assets and enforce their exclusive rights" [12]. Yet he also points to that there is no explicit definition to transaction costs just as there is no correct definition to production costs in neoclassical theory. Robert Mathews proposed the following definition: "the fundamental idea of transaction costs consists in that they encompass the costs of drawing up and concluding a contract, as well as the costs of supervising compliance with the contract and ensuring its fulfilment as opposed to production costs, which are the costs of the performance of the contract itself" [18].

These definitions allow us to identify three key dependencies of transaction costs on the parameters of economic systems. According to T. Eggertsson, transaction costs are directly proportional to the number of economic agents contracting each other. And in line with the definition of R. Matthews, transaction costs are inversely proportional to the number of contracts concluded and the established norms that ensure the implementation of these contracts.

If under formal contracts we understand formal institutions, and under rules that ensure the implementation of these contracts - informal institutions, then it is possible to qualitatively model the dependence of transaction costs on the basic institutional parameters of economic systems.

In this case, the exogenous transaction function of the firm will take the form [19]:

$$
C=\frac{B \cdot N^{\lambda}}{F^{\mu}+I^{v}}
$$

where $C$ is transaction costs of a firm (economic agent in a general case); $B$ is coefficient of proportionality, measured in the units of costs; $N$ is the number of economically active agents (actors) that have entered into institutional arrangements with a firm (or a certain agent); $F$ is the number of formal institutions (contracts); $I$ is the number of informal institutions; $\lambda, \mu, v$ are the coefficients of elasticity of the use of actors, formal and informal institutions for the formation of the institutional environment.

In equation (1), formal and informal institutions are represented as additive terms, since they supplement, but do not overlap various directions of economic activity with their norms. In other words, in each concrete situation, contractual relations can be defined in the form of formalized (classical and neoclassical) norms, or in the form of informal (implicit) agreements between economic agents.

Expression (1) describes the exogenous transaction function of the firm, since accounting for endogenous factors would have led to the need to analyse internal transactions and, accordingly, change the form of the ratio.

Another example of analytical institutional modelling is the model for optimizing the transaction costs of information production and consumption. Let us define the conditions under which a firm is at the level of transaction costs of information production and consumption, 
which is optimal for this evolutionary period of time. The model presented in this study is based on the modification of Williamson's model of spending preferences [9. P. 241]. In order to determine the optimal cost of information production and consumption, we need to deal with the following problems:

- to maximize the profit of the firm;

- to maximize the completeness of information;

- to comply with the budget constraint.

The profit function of the firm in our model takes the form:

$$
\pi(Q, I C)=R(Q, I C)-C(Q)-I C,
$$

where $\pi$ is net profit, $Q$ is output, $I C$ is transaction costs of information production and consumption, $R$ is gross revenue, $C$ is production costs.

Consider the following model assumptions:

1. The revenue $R$ in the model depends not only on the output $Q$, but also on the information production costs IC. This means that an increase in the costs of information production and consumption leads to an increase in gross revenue associated with obtaining additional information about the market and earning additional revenue.

2. The above expression (2) is the budget constraint of the model. The firm can direct all received revenue either to increase net profit, or to produce and search for information.

3. The costs of information production and consumption are fixed and do not depend on the output. Despite the fact that some types of transaction costs of information production and consumption may depend on $Q$, it can be assumed that in the short run they are fixed costs.

The task of profit maximization is limited to the following expression:

$$
\max \pi(Q, I C)=R(Q, I C)-C(Q)-I C \text {. }
$$

By differentiating the right-hand side of equation (3) with respect to the parameter $I C$ and equating it to zero, we obtain the following condition:

$$
\frac{\partial \pi}{\partial I C}=\frac{\partial R}{\partial I C}-1=0
$$

Therefore [20]:

$$
\frac{\partial R}{\partial I C}=1
$$

Condition (5) is a condition for the optimum amount of costs of information production and consumption $I C$ and assumes that the growth rate of transaction costs should be equal to the growth rate of gross revenue. Thus, an increase in transaction costs $I C$ by $1 \%$ should result in an increase in revenue by $1 \%$.

Hence, the methods of institutional modelling can be successfully applied to forecast the development of the institutional infrastructure of the objects of digital society.

\section{Conclusion}

The development of the elements of analysis of modern digital society within the author's concept of econotronics has yielded a number of results.

First, econotronics has been defined as a subfield of social sciences studying the development dynamics of economic institutions of interaction between actors and society in a modern digital economy.

Second, we have demonstrated that the research subject of econotronics includes social innovations, crowdfunding, as well as other economic processes which gained traction within modern digital society. Sharing economy and blockchain technology exemplify a typical subject of econotronics. 
Third, in a narrower sense, a modelled representation, the research subject of econotronics encompasses economic institutions of interaction between actors and society. At this, the analysis of development dynamics of these institutions matters greatly.

Fourth, we have considered the principles of institutional design of the subject of econotronics at the example of institutional design of transactions in sharing economy and blockchain technology.

Fifth, we have pointed to that institutional modelling of digital society within the concept of econotronics can be done by the methods of matrix, parametric, graphical and analytical modelling

The methods of econotronics act as a methodological platform for modelling of rational economic management under the use of digital technologies. Stated differently, econotronics is a scientific concept to describe the development of digital society.

\section{References}

1. Ananyin O. I., Odintsova M.I. Metodologiya ekonomicheskoy nauki: sovremennye tendentsii i problemy [The methodology of economic science: Modern trends and problems]. In: ISTOKI. Vyp. 4 [The Beginnings. Issue 4]. Moscow: Institue of Economics of RAS, 2000, pp. 135-136.

2. Avtonomov V., Ananyin O., Makasheva N. Istoriya ekonomicheskikh ucheniy [The history of economic thought]. Moscow: INFRA-M Publ., 2001.

3. Makarov V.L. Ischislenie institutov [Calculus of institutions]. Ekonomika i matematicheskie metody - Economics and Mathematical Methods, 2003, vol. 39, no. 2, pp. 14-37.

4. Marx K., Engels F. Sobraniye sochineny. T. 3 [Collected works. Vol. 3]. Moscow: Politizdat Publ., 1955.

5. Polterovich V.M. Optimal'nyy vybor ekonomicheskikh institutov [The optimal choice of economic institutions]. Ekonomika i matematicheskie metody - Economics and Mathematical Methods, 2003, vol. 39, no. 4, pp. 52-58.

6. Popov E. V. Instituty [Institutions]. Yekaterinburg: Institute of Economics (Ural branch of RAS), 2015.

7. Popov E. V. Ekonotronika [Econotronics]. Ekonomika regiona - Economy of Region, 2018, vol. 14, issue 1, pp. 13-28.

8. Sergeev A.M. Metodologicheskie osobennosti i problemy novogo institutsionalizma [Methodological specifics and problems of new institutionalism]. Yekaterinburg: Institute of Economics (Ural branch of RAS), 2005.

9. Furubotn E., Richter R. Instituty i ekonomicheskaya teoriya [Institutions and economic theory]. Saint Petersburg: Saint Petersburg State University, 2005.

10. Hodgson G. Evolyutsiya institutov: napravleniya budushchikh issledovaniy [The evolution of institutions: An agenda for future research]. Zhurnal ekonomicheskoy teorii-Russian Journal of Economic Theory, 2005, no. 2, pp. 5-22.

11. Shastitko A. Ye. Novaya institutsional'naya ekonomicheskaya teoriya [New institutionalism]. Moscow: TEIS Publ., 2002.

12. Eggertsson T. Ekonomicheskoe povedenie i instituty [Economic behavior and institutions]. Moscow: Delo Publ., 2001.

13. Gouldner A.W. The Dialectic of Ideology and Technology: The Origins, Grammar and Future. N. Y.: The Free Press, 1976.

14. Etzioni A. The Moral Dimension: Toward a New Economics. N. Y.: The Free Press, 1988.

15. Faith B., Prieto-Martin P. Civil Society and Civic Engagement in a Time of Change. Institute of Development Studies Bulletin, 2016, vol. 47, no. 2A, pp. 137-144.

16. Fletcher G., Greenhill A., Griffiths M., McLean R. The Social Supply Chain and the Future High Street. Supply Chain Management, 2016, vol. 21, no. 1, pp. 78-91. 
17. Hodgson G.M. What Are Institutions? Journal of Economic Issues, 2006, vol. XL, no. 1, pp. 1-26.

18. Matthews R. C. O. The Economics of Institutions and Sources of Growth. Economic Journal, 1986, vol. 96, no. 12 (December), pp. 903-910.

19. Popov E. V. Transaction Function. International Advances in Economic Research, 2008, vol. 14 , no. 4 , pp. $474-475$.

20. Popov E. V., Konovalov A. A. Institutional Effects Estimation in the Sphere of Economical Information. Montenegrin Journal of Economics, 2007, no. 5, pp. 59-66.

21. Swan M. Anticipating the Economic Benefits of Blockchain. Technology Innovation Management Review, 2017, vol. 7, no. 10, pp. 6-13.

22. Szetela B., Mentel G. May the Sharing Economy Create a New Wave of Globalization? Economic Annals, 2016, vol. 161, no. 9-10, pp. 31-34.

23. Veblen T. Why is Economics not an Evolutionary Science. Quarterly Journal of Economics, 1898, vol. 12, no. 4, pp. 373-397.

24. Veblen T. The Place of Science in Modern Civilization and Other Essays. N. Y.: Huebsch, 1919.

\section{Эконотроника цифрового общества'}

\section{E. B. Попов}

Исследование направлено на систематизацию элементов анализа современного цифрового общества в рамках авторской концепции эконотроники. Показано, что эконотроника представляет собой раздел социальных наук о динамике развития экономических институтов взаимодействия между акторами и обществом в цифровой экономике. Проанализированы объекты исследования эконотроники. На основе современного представления о человеке институциональном определено, что наиболее адекватным аппаратом моделирования процессов развития цифрового общества являются инструменты институциональной экономической теории. Выявлены элементы институционального дизайна трансакций эконотроники. Выделены направления институционального моделирования объектов эконотроники. Утверждается, что эконотроника является научной концепцией моделирования развития цифрового общества.

Ключевые слова: цифровое общество; эконотроника; человек институциональный; институциональный дизайн; моделирование.

\section{Источники}

1. Ананьин О.И., Одинцова М.И. Методология экономической науки: современные тенденции и проблемы // ИСТОКИ. Вып. 4. М.: ИЭ РАН, 2000. С. 135-136.

2. История экономических учений / под ред. В. Автономова, О. Ананьина, Н. Макашевой. М.: ИНФРА-М, 2001. С. 654-656.

3. Макаров В. Л. Исчисление институтов // Экономика и математические методы. 2003. Т. 39, № 2. C.14-37.

4. Маркс К., Энгельс Ф. Собр. соч. М.: Политиздат, 1955. Т. 3.

5. Полтерович В.М. Оптимальный выбор экономических институтов // Экономика и математические методы. 2003. Т. 39, № 4. С. 52-58.

6. Попов Е. В. Институты. Екатеринбург: Ин-т экономики УрО РАН, 2015.

7. Попов Е. В. Эконотроника // Экономика региона. 2018. Т. 14, вып. 1. С. 13-28.

8. Сергеев А.М. Методологические особенности и проблемы нового институционализма: препринт. Екатеринбург: Ин-т экономики УрО РАН, 2005.

${ }^{1}$ Статья выполнена при финансовой поддержке РФФИ (проект № 17-06-00281 «Моделирование институциональной среды социально-инновационного развития России»). 
9. Фуруботн Э., Рихтер Р. Институты и экономическая теория. СПб.: Изд. дом СПбГУ, 2005.

10. Ходжсон Дж. Эволюция институтов: направления будущих исследований // Журнал экономической теории. 2005. № 2. С. 5-22.

11. Шаститко А.Е. Новая институциональная экономическая теория. М.: ТЕИС, 2002.

12. Эггертссон Т. Экономическое поведение и институты. М.: Дело, 2001.

13. Gouldner A. W. The Dialectic of Ideology and Technology: The Origins, Grammar and Future. N. Y.: The Free Press, 1976.

14. Etzioni A. The Moral Dimension: Toward a New Economics. N. Y.: The Free Press, 1988.

15. Faith B., Prieto-Martin P. Civil Society and Civic Engagement in a Time of Change // Institute of Development Studies Bulletin. 2016. Vol. 47, no. 2A. Pp. 137-144.

16. Fletcher G., Greenhill A., Griffiths M., McLean R. The Social Supply Chain and the Future High Street // Supply Chain Management. 2016. Vol. 21, no. 1. Pp. 78-91.

17. Hodgson G. M. What Are Institutions? // Journal of Economic Issues. 2006. Vol. XL, no. 1. Pp. 1-26.

18. Matthews R. C. O. The Economics of Institutions and Sources of Growth // Economic Journal. 1986. Vol. 96, no. 12. Pp. 903-910.

19. Popov E. V. Transaction Function // International Advances in Economic Research. 2008. Vol. 14, no. 4. Pp. 474-475.

20. Popov E. V., Konovalov A. A. Institutional Effects Estimation in the Sphere of Economical Information // Montenegrin Journal of Economics. 2007. No. 5. Pp. 59-66.

21. Swan M. Anticipating the Economic Benefits of Blockchain // Technology Innovation Management Review. 2017. Vol. 7, no. 10. Pp. 6-13.

22. Szetela B., Mentel G. May the Sharing Economy Create a New Wave of Globalization? // Economic Annals. 2016. Vol. 161, no. 9-10. Pp. 31-34.

23. Veblen T. Why is Economics not an Evolutionary Science // Quarterly Journal of Economics. 1898. Vol. 12, no. 4. Pp. 373-397.

24. Veblen T. The Place of Science in Modern Civilization and Other Essays. N. Y.: Huebsch, 1919.

Сведения об авторе:

E. В. Попов, чл.-кор. РАН, д-р экон. наук, руководитель центра экономической теории, заведующий кафедрой политической экономии

Контактный телефон: (343) 371-45-36

e-mail: epopov@mail.ru

\author{
Институт экономики УрО РАН \\ 620014, РФ, Екатеринбург, ул. Московская, 29 \\ Уральский государственный экономический \\ университет \\ 620144, РФ, г. Екатеринбург, \\ ул. 8 Марта/Народной Воли, 62/45
}

Ссылка для цитирования: Рopov E. V. Econotronics of the Digital Society// Известия Уральского государственного экономического университета. 2018. T. 19, №3. C. 8-17. DOI: 10.29141/2073-1019-2018-19-3-2

For citation: Popov E. V. Econotronics of the Digital Society. Izvestiya Uralskogo gosudarstvennogo ekonomicheskogo universiteta - Journal of the Ural State University of Economics, 2018, vol. 19, no. 3, pp. 8-17. DOI: 10.29141/20731019-2018-19-3-2 